\title{
Sudan's approach to knowledge management in disaster management
}

\author{
M. A. E. Boshara ${ }^{1}$, P. C. Woods ${ }^{2}$ \& N. E. M. Elshaiekh ${ }^{1}$ \\ ${ }^{1}$ Future University, Sudan \\ ${ }^{2}$ Multimedia University, Malaysia
}

\begin{abstract}
An incident tracing system (ITS) is an online rapid assessment system to track and monitor disasters that may affect the country. A mixed method used to collect needed data to conduct the research (documents, interviews, and observations). It is composed of a set of modules implemented by a coordinated group of humanitarian experts to support the core functions that should be undertaken in disasters. The tools implemented for disaster risk management program monitoring. The initiative was focused on linking the humanitarian actors and providing a platform for collaboration. This collaborative online platform should facilitate interaction and assist the exchange of knowledge. This paper proposes the implementation of ITS as a comprehensive knowledge management system for disaster management with a sustainable data collection mechanism for reliable and timely information management to support decision makers in making the right decisions in a timely manner. ITS explains how KM can be brought to non-normal situations (disasters) and decision-making in disaster management practice. In a country like Sudan, ITS has played a valuable role in achieving disaster management objectives by leveraging existing knowledge, converting new knowledge into action and aid in early warning.

Keywords: knowledge management, disaster management, incident tracking system, web application.
\end{abstract}

\section{Introduction}

The main anticipated threats to public health in Sudan are natural disasters, conflicts and epidemics. Natural disasters like floods have adverse effects on many states. About $18 \%$ of the population is severely affected every year during 
the rainy season (June-September). Also, drought comprises a real hazard in certain states, for example West and South Darfur, affecting about $10 \%$ of the population. Some parts of the country are affected by heat waves while others are affected by dust storms (central area), earthquakes and landslides. Protecting human health is a key imperative for reducing risks to communities, including those that lead to emergencies and disasters when they are on a scale that overwhelms the local capability. Public health professionals require accurate data and the ability to have access to data quickly. The knowledge and experience of disasters remain in the individual or institutional domain. There is an urgent need for a common platform to capture, organize and share this knowledge.

\section{Literature review}

\subsection{Disaster risk reduction (DRR)}

The concept and practice of reducing disaster risks through systematic efforts to analyse and manage causal factors of disasters [1].

\subsection{Knowledge management concept and principles}

Knowledge Management (KM) is defined as an organization or community's planned approach to collecting, evaluating, cataloguing, integrating, sharing, improving, and generating value from its intellectual and information-based assets. KM refers to the entire process of acquisition, management, and utilization of disaster information and knowledge for the support of humanitarian operations [2]. KM is responsible for determining what information is needed and for overseeing the acquisition and dissemination of information. Improving KM efficiency can not only assist decision-makers in doing their job faster, cheaper, and better, but also enable various groups to share and reuse different resources. It is the key to the success of real-time decision making.

\subsection{Knowledge management system}

A knowledge management system (KM system) refers to a system for managing knowledge in organizations for supporting creation, capture, storage and dissemination of information, generally a KM system is computer based. KM systems deal with information so they are a class of information systems and may build on, or utilize other information sources. A computer-based KM system includes a database that contains knowledge items and an activity record that is associated with the knowledge items [3], stated that KM systems are vital for disaster detection, response planning, and management. These systems aid in early warning, and provide decision support for disaster response and recovery management.

\subsection{KM common tools and practices}

It is useful to understand the range of tools and practices that may be involved. Three main cross sectional groups describe KM tools and practices. Creating and 
discovering, organizing and managing and sharing and learning. The tools and practices in the first two groups are concerned largely with handling explicit knowledge and information, whilst those in the last group (with the exception of sharing best practice) are more focused on the exchange of tacit knowledge [4]. (Table 1) provides a detailed explanation of KM common tools and practices [5].

\subsection{The role of information and knowledge in disaster management}

Information and knowledge have become important issues in healthcare as medical practice requires tools to extend the mind's limited capacity and to recall and process large numbers of relevant variables. Furthermore information and KM (IKM) enable and sustain informed decision-making for managing disaster risk and are essential for coordinated action. Informed decision-making needs a sound information and knowledge base as well as dedicated and skilled professionals [1].

\subsection{Issues in information and KM for disaster management}

Below are selected issues identified by the UNISDR framework that underline the need for a systematic approach to guide the development of IKM systems at all levels:

- Information is scattered among various agencies and institutions with limited coherence, coordination and sharing.

- Information about hazard events, exposure, vulnerability, and the impacts of disasters is often not systematically collected.

- Limited analysis has been done to understand the trends, spatial and temporal impacts of potential disaster risks and their impacts.

- Risk information is not systematically used for policy and decisionmaking.

- There are no agreed upon standards and shared definitions in IKM for disaster risk reduction.

- There is little integration of knowledge systems at regional, national and community levels.

- Civil society and private sector involvement is often limited.

- Cultural context as a major influence to approaches in disaster risk reduction and disaster risk management is rarely considered.

- Incentives and political backing for information sharing are insufficient or lacking, and responsibilities and accountabilities for IKM are not defined.

- Issues of power and competition at institutional and other levels get in the way of sharing information.

- Dedicated capacity and skill development in information and knowledge management are lacking.

- $\quad$ Resources are not committed for sustainable IKM initiatives. 
Table 1: KM common tools and practices.

\begin{tabular}{|c|c|c|}
\hline $\begin{array}{l}\text { Creating and } \\
\text { discovering }\end{array}$ & Organizing and managing & Sharing and learning \\
\hline $\begin{array}{l}\text { Creativity techniques } \\
\text { Going beyond } \\
\text { techniques such as } \\
\text { Brainstorming or } \\
\text { concept mapping, } \\
\text { knowledge initiatives } \\
\text { geared towards } \\
\text { innovation might } \\
\text { involve creativity } \\
\text { training, and establish } \\
\text { organizational routines } \\
\text { and policies to } \\
\text { encourage creative } \\
\text { problem solving and } \\
\text { new ideas. }\end{array}$ & $\begin{array}{l}\text { Expertise profiling } \\
\text { Identifying and recording } \\
\text { information on people's } \\
\text { skills and knowledge, } \\
\text { usually in the form of a } \\
\text { database of available } \\
\text { skills that can be searched } \\
\text { by anyone in the } \\
\text { organization. }\end{array}$ & $\begin{array}{l}\text { Communities of } \\
\text { practice Nurturing } \\
\text { and supporting } \\
\text { informal networks } \\
\text { spanning } \\
\text { departmental and } \\
\text { organizational } \\
\text { boundaries, where } \\
\text { knowledge is } \\
\text { exchanged and issues } \\
\text { can be addressed } \\
\text { outside of the normal } \\
\text { organizational } \\
\text { hierarchy. These } \\
\text { may be based on face } \\
\text { to face contact or } \\
\text { electronic networks. }\end{array}$ \\
\hline $\begin{array}{l}\text { Data and text mining } \\
\text { Techniques that use } \\
\text { computers to identify } \\
\text { potentially significant } \\
\text { patterns and } \\
\text { relationships in large } \\
\text { volumes of data or } \\
\text { from large documents. }\end{array}$ & $\begin{array}{l}\text { Information or } \\
\text { knowledge inventories } \\
\text { Recording what } \\
\text { information or knowledge } \\
\text { exists in an organization } \\
\text { and how it is used, as an } \\
\text { aid to other knowledge } \\
\text { management practices. }\end{array}$ & $\begin{array}{l}\text { Learning networks } \\
\text { More formal than } \\
\text { communities of } \\
\text { practice, with a } \\
\text { primary focus on } \\
\text { personal } \\
\text { development and } \\
\text { organizational } \\
\text { learning. }\end{array}$ \\
\hline $\begin{array}{l}\text { Environmental } \\
\text { scanning } \\
\text { Systematic scanning } \\
\text { of the external } \\
\text { environment to gather } \\
\text { intelligence. } \\
\text { Increasingly, } \\
\text { knowledge workers } \\
\text { are able to set up feeds } \\
\text { of relevant } \\
\text { information to be } \\
\text { delivered directly from } \\
\text { the web. }\end{array}$ & $\begin{array}{l}\text { Information resource } \\
\text { management Managing } \\
\text { explicit knowledge as an } \\
\text { organizational resource, } \\
\text { for example through } \\
\text { establishing a centralised } \\
\text { library or information } \\
\text { store, or by cataloguing } \\
\text { and assigning ownership } \\
\text { of distributed information } \\
\text { assets. }\end{array}$ & $\begin{array}{l}\text { Sharing best } \\
\text { practice } \\
\text { Comparing your } \\
\text { organization's } \\
\text { practices in a given } \\
\text { activity with those of } \\
\text { other organizations } \\
\text { through } \\
\text { benchmarking, bench } \\
\text { learning, conferences } \\
\text { or informal } \\
\text { networking. Similar } \\
\text { practices can take } \\
\text { place internally } \\
\text { between teams. }\end{array}$ \\
\hline
\end{tabular}


Table 1: Continued.

\begin{tabular}{|l|l|l|}
\hline $\begin{array}{l}\text { Creating and } \\
\text { discovering }\end{array}$ & Organizing and managing & Sharing and learning \\
\hline $\begin{array}{l}\text { Knowledge elicitation } \\
\text { interviewed or } \\
\text { shadowed in order to } \\
\text { extract and articulate } \\
\text { their tacit knowledge } \\
\text { into a more explicit } \\
\text { and widely accessible } \\
\text { form. }\end{array}$ & $\begin{array}{l}\text { Intranets and } \\
\text { groupware } \\
\text { Enabling information to } \\
\text { be quickly published } \\
\text { shared and then retrieved, } \\
\text { wherever a person is } \\
\text { located. Culture, } \\
\text { procedures and practices } \\
\text { are often as important as } \\
\text { the underlying technology } \\
\text { for creating a valuable } \\
\text { knowledge resource. }\end{array}$ & $\begin{array}{l}\text { After action reviews } \\
\text { (or post project } \\
\text { review) Setting up a } \\
\text { structured process } \\
\text { where key } \\
\text { participants ask what } \\
\text { went well, what went } \\
\text { wrong, what has } \\
\text { been learned, and } \\
\text { how to do it } \\
\text { differently next time. } \\
\text { Results are recorded } \\
\text { and shared, and } \\
\text { systems and } \\
\text { procedures changed } \\
\text { where necessary. }\end{array}$ \\
\hline $\begin{array}{l}\text { Scenario planning } \\
\text { The effects of different } \\
\text { potential scenarios are } \\
\text { modelled or played } \\
\text { out, often as a group } \\
\text { exercise, in order to } \\
\text { reveal new insights } \\
\text { into the organization. }\end{array}$ & $\begin{array}{l}\text { Measuring the value of } \\
\text { knowledge } \\
\text { Developing indicators to } \\
\text { track the growth and } \\
\text { development of } \\
\text { knowledge within the } \\
\text { organization. As the } \\
\text { saying goes: 'what gets } \\
\text { measured gets managed'. }\end{array}$ & $\begin{array}{l}\text { Cross } \\
\text { teams } \\
\text { Bringing together } \\
\text { people with different } \\
\text { perspectives, } \\
\text { knowledge and } \\
\text { experience with the } \\
\text { aim of improving } \\
\text { innovation and } \\
\text { validating ideas and } \\
\text { plans. }\end{array}$ \\
\hline
\end{tabular}

\subsection{Sudan's approach to $\mathrm{KM}$ in disaster management practice}

The Federal Ministry of Health (FMOH) in cooperation with World Health Organization (WHO) Sudan office have taken the initiative to establish an IKM System to be used as an online tool for detection, response planning, and management of disasters. The system aims to connect all Sudan states to share the information and knowledge about disaster past or future. A mixed method used to collect needed data to conduct the research (documents, interviews, and observations). The system composed of set of modules implemented by a coordinated group of humanitarian experts to support the core functions that should be undertaken in disasters. 


\subsubsection{Creating an environment for $\mathrm{KM}$}

The initiative is focused at linking the humanitarian actors and providing a platform for collaboration. This collaborative online platform should facilitate interaction and assist exchange of knowledge.

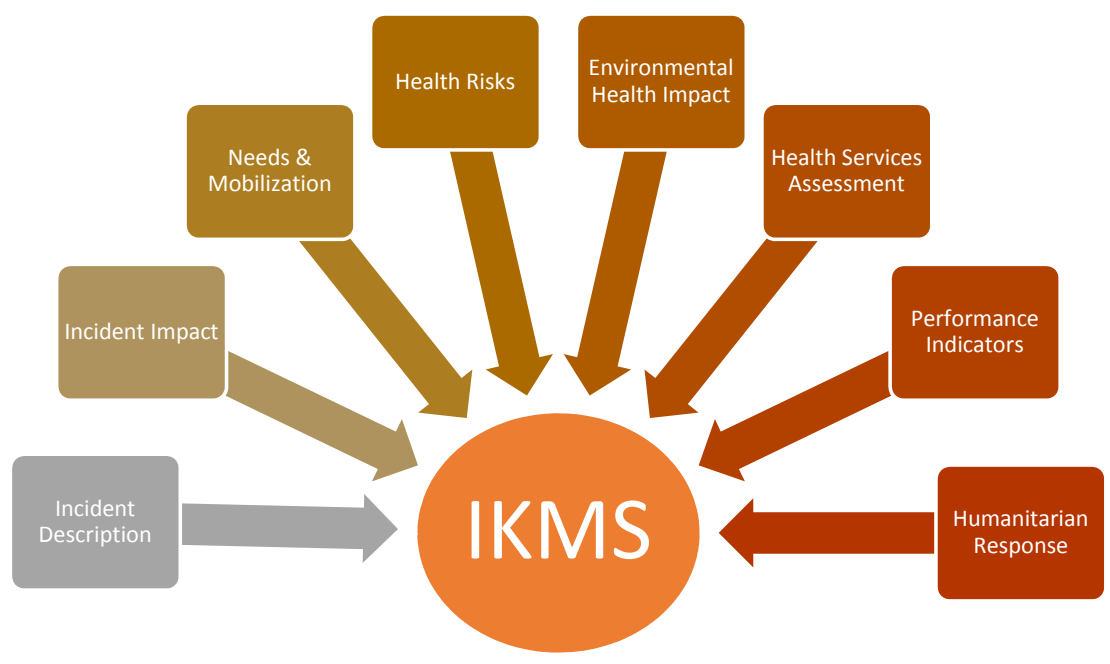

Figure 1: IKMS platform for disaster management derived from [6].

\subsubsection{Incident tracking system: tool for $\mathrm{KM}$}

An incident tracing system (ITS) is an online rapid assessment system to track and monitor disasters that may affect the country. It is composed of a set of modules implemented by a coordinated group of humanitarian experts to support the core functions that should be undertaken in disasters. The tools implemented for disaster risk Management program monitoring [6].

ITS developed to achieve the following set of objectives:

- Incident command and control to ensure consistency and follow-up.

- Sustainable data collection mechanism for reliable and timely information management.

- Support of decision making to initiate planning.

- Prioritizing actions, allocating resources and monitoring changes.

- Program monitoring and methodology sharing tools.

- Knowledge base for disasters.

- Ensure prompt response from the concerned parties. 


\subsubsection{ITS framework}

ITS is a web based system operating on internet and controlled by access levels. Users at state level are sharing their disasters status and progress in the ITS. ITS is capturing information such as incident description, incident impact, vital needs, management plans, documents, reports, etc. The modules of the ITS is built base on DRM expert requirement.

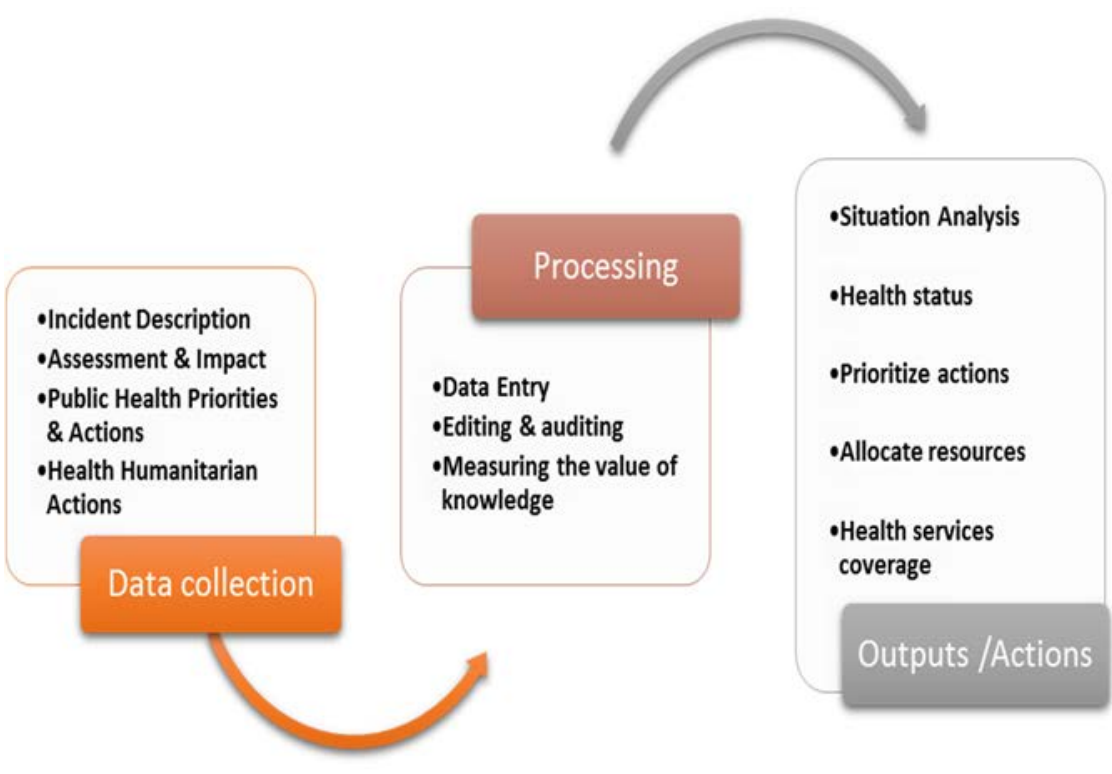

Figure 2: $\quad$ ITS framework Sudan approach derived from [6].

\section{Conclusion}

Incident tracking system explains how $\mathrm{KM}$ can be brought to non-normal situations (disasters) and decision-making in disaster management practice. In principle, knowledge organization and lesson learned from previous disasters can be a foundation for disaster detection, response and planning, KMS like ITS will play a valuable role in achieving disaster management objectives, by leveraging existing knowledge, converting new knowledge into action and aid in early warning. Managing past knowledge for reuse can expedite the process of disaster response and recovery management.

The IKM system for disasters requires solid information and knowledge base as well as dedicated and skilled professionals. 

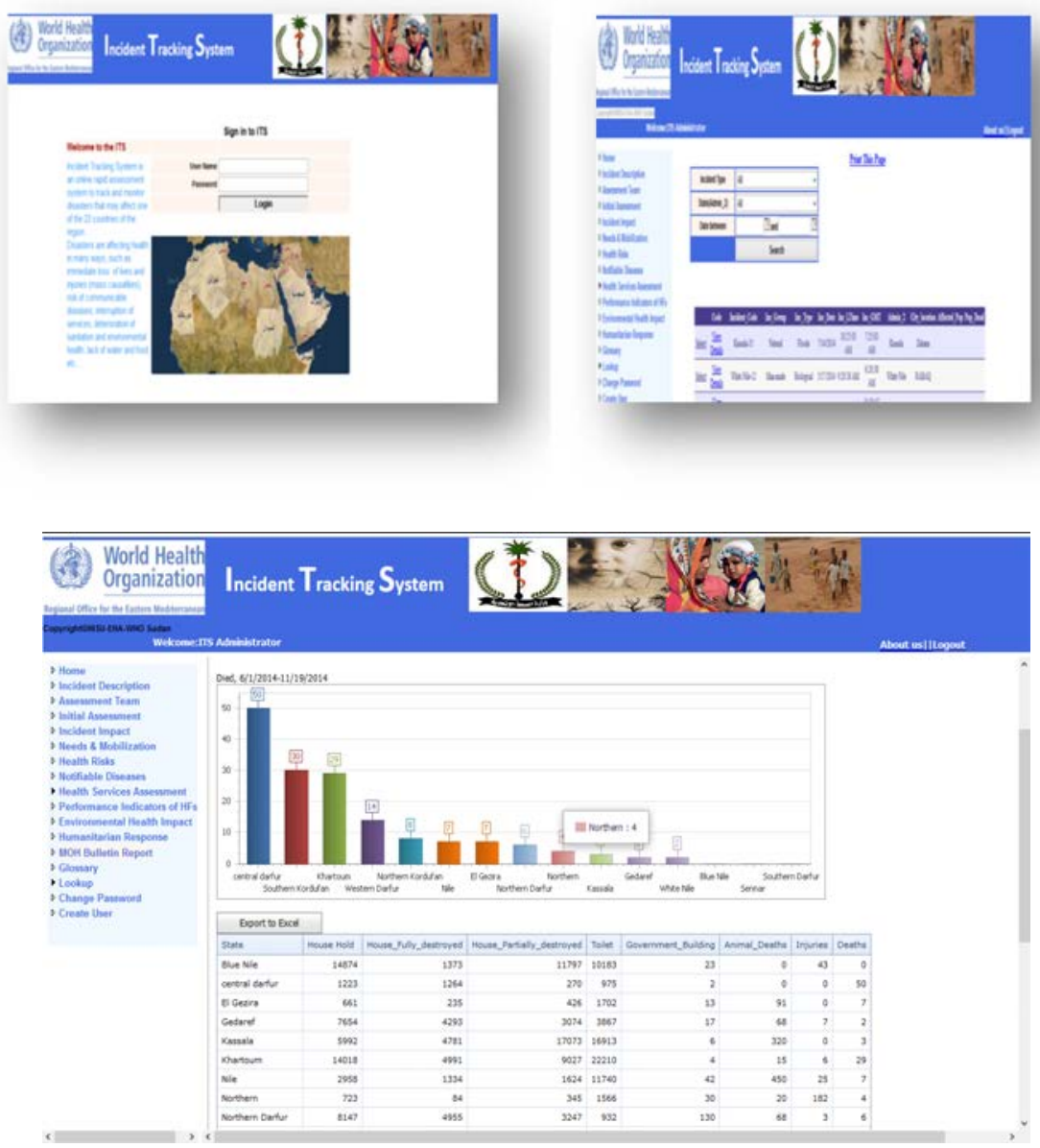

Figure 3: $\quad$ ITS snapshots derived from [7].

\section{References}

[1] UNISDR, "Information and Knowledge Management for Disaster Risk Reduction (IKM4DRR) Framework and Scorecard,” 2013.

[2] D. \&. Z. L. \&. F. N. Zhang, A Knowledge Management Framework for the Support of Decision Making in Humanitarian Assistance/Disaster Relief, 2002.

[3] T. a. J. M. Murphy, Knowledge Management, Emergency Response, and Hurricane Katrina, International Journal of Intelligent Control Systems, 2006.

[4] S. Kermally, Effective Knowledge Management: A Best Practice Blueprint (CBI Fast Track), John Wiley \& Sons, 2002.

[5] Sayer Vincent, Knowledge Management Made Simple, 2009. 
[6] WHO-Sudan, “Incident tracking User manual,” 2008.

[7] WHO and FMOHSudan, "Incident tracking web application-Sudan," [Online].

[8] I. Nonaka and Takeuchi, "The Knowledge-Creating Company: How Japanese Companies Create the Dynamics of Innovation”.

[9] S. a. a. Mohanty, "Knowledge Management in Disaster Risk Reduction," 2005. 